J. Product. \& Dev., 26(4): 703-718 (2021)

\title{
EFFECT OF SOME MANGO ROOTSTOCKS ON THE PERFORMANCE OF KEITT,NAOMI AND HAYDI MANGO VARIETIES
}

Manar M.A. Hamed, S.A. Mehana and Nermeen I. El Naggar

Plant production Department, Faculty of Technology and development, Zagazig university, Egypt.

e.mail:nielnagar@hotmail.com, saeedmehana@yahoo.com

\section{ABSTRACT}

This investigation was carried out during the two consecutive seasons (2019 and 2020) respectively on mango trees (Mangifera indica L.) cvs. "Keitt,Naomi and Haydi" grown in a private orchard at El Salhia region, Sharkia Governorate, Egypt. In a sandy soil and irrigated with drip irrigation system.Trees were 7-year-old,planted at $2 * 4 m$ space to evaluate the effect of some mango rootstocks (Balady and succary) on vegetative growth, flowering, fruiting, yield and fruit quality of these mango varieties "Keitt,Naomi and Haydi"

There is a relationship between the rootstocks of mango trees and their scions including vegetative, flowering characters and also yield in quality and quantity. AS for vegetative characters, the thickness of rootstocks and scions zones, which showed the differences in Keitt ,Naomi and Haydi varieties.That gave more thick in Keitt than the other varieties.Also, showed that Balaby rootstocks of came more thick than Succary one in this study. The leaf area was affected in this study in two seasons, however leaf area of Keitt and Naomi varieties gave ahigh measureable than Haydi leaf area in both season of study. Average number of sprouts in spring time, summer time and also autumn time .The number of Haydi,Naomi and late Keitt in descending order.The number of sprouts in the time of spring followed by summer sprouts.The floral characters was affected by rootstocks markedly .however, panicle length showed that more length with the rootstock of Balady than Succary with variety of Keitt and Naomi while the Succary rootstock gave more length in variety of Haydi than the other Keitt and Naomi in the two seasons. As for branches number/panicle in Keitt variety on Balady and Succary rootstocks had shown significantly differences. The Naomi and Haydi appeared a variance in large number in Succary rootstock than Balady. 
Fruit physical properties was also affected significantly by rootstocks as fruit length, width and shape index.In addition, fruit weight and pulp weight showed that Succary rootstock gave more fruit weight and pulp weight than Balady rootstock. Also fruit chemical properties as TSS, total acidity percentage ,TSS/acid ratio, carotene ( $\mathrm{mg} / 100 \mathrm{gm})$ and vitamin $C(\mathrm{mg} / 100 \mathrm{ml})$ showed a significantly differences in both seasons of study.

Conclusively, from these results of this research, the rootstock of Succary gave more yield /tree as the other rootstock of Balady one in the two seasons of study with trees were-7-year old.

Key words: Mango Rootstocks, Performance, Keitt, Naomi, Haydi .

\section{INTRODUCTION}

There are some relationships between scions and rootstocks in the grafting of fruit trees in features of vegetative, flowering and yield. The vegetative status in this concern as clearly leaf area, new branches or sprout has been the numbers, lengths and canopy definitely differed from trees especially in mango trees according to (Amin 1978; Reddy et al., 2003 and Duran Zuazu ,2006).

Number of shoots and leaves of mango cultivars in addition showed a significant variety in scions height with age of rootstocks at 50 days after the sprouting (Kaur and Malhi 2006). New sprouts diameter was significantly influenced by rootstocks age. Omayma and Sanaa (2013) showed that the greatest Kiett variety leaf area was $76.58 \mathrm{~cm}^{2}$ following by Hindi $60.85 \mathrm{~cm}^{2}$

On other hand, Zayan et al (2020) studied the effect of rootstocks on leaf chlorophyll $\mathrm{a}, \mathrm{b}$ and its total content.

So, the flowering status as being effected by the relationship between scion and rootstock of mango cutivars was studied for initiation time of panicles ,total flowers number and the proporation of male to hermaphrodite flowers Asif et al., (2002). Smith et al (2003) showed that rootstock had a greatest influence on yield starting when the trees were about four years and containg more years after grafting

Othman and Mbogo (2009) recorded that the late mango fruits season had the greatest ascorbic acid content when harvested, while early season fruits had the least values within season. Appiah et al (2011) showed that total soluble solids values recorded a significant increase in mango pulp from $7.00 \%$ to $15.95 \%$. Vitamin $\mathrm{C}$ content recorded a significant decline from 29.08 
$\mathrm{mg} / 100 \mathrm{~g}$ to $3.45 \mathrm{mg} / 100 \mathrm{gm}$. Titratable acidity content in mango fruit illustrated a significant decrease with ripening .

Avilan et al (1997) illustrated that the rootstocks had modified the dimension of fruits, shape and weight for Tommy atkins and Haden indicated that fruit weight and size increasing.

\section{MATERIALS AND METHODS}

This investigation was carried out during two consecutive seasons (2019 and 2020) respectively on mango trees (Mangifera indica L.) cvs. "Keitt,Naomi and Haydi " grown in a private orchard at El Salhia region, Sharkia Governorate , Egypt. Trees were 7-year-old ,planted at $2 * 4 \mathrm{~m}$ space in a sandy soil and irrigated with drip irrigation system, grown under the same common agricultural practices .Eighteen healthy trees/season were selected nearly similar in vigor and size to evaluate the effect of some mango rootstocks (Balady and Succary ) on vegetative growth ,flowering, fruiting and yield of "Keitt, Naomi and Haydi " mango varieties.

\subsection{The experiment included six treatments as follows/}

1- Keitt scion grafted on balady rootstock.

2- Keitt scion grafted on Succary rootstock.

3- Naomi scion grafted on balady rootstock.

4- Naomi scion grafted on Succary rootstock.

5- Haydi scion grafted on balady rootstock.

6- Haydi scion grafted on Succary rootstock.

\section{Studying parameters}

During the two seasons of study, the response of vegetative growth, flowering, fruiting and yield performed as follows:

\subsection{Vegetative Growth characteristics:}

3.2.1. Scion and rootstock diameter: By using digital vernier caliper ( $\mathrm{mm}$ ) in two successive seasons.

3.2.2. Average leaf area: Samples of mature leaves grown on unfruitful shoots randomly taken at harvest date, length and width of leaf $(\mathrm{cm})$ were measured .This average leaf surface area $\left(\mathrm{cm}^{2}\right)$ was determind according to the equation reported by Ahmed and Morsy (1999) as:

Leaf area $\left(\mathrm{cm}^{2}\right)=0.7$ (Blade length $\times$ Blade width) -1.06

3.2.3. Spring growth cycle: Number of Spring growth shoots on March and April.

3.2.4. Summer growth cycle: Number of Summer growth shoots on May and June 
3.2.5. Autumn growth cycle: Number of Autumn growth shoots on October and November.

\subsection{Flowering characteristics:}

\subsubsection{Panicle properties:}

1- Length of panicle $(\mathrm{cm})$

2- Branches number / panicle were taken after full bloom.

3.4. Fruits number and yield/tree: The number of fruits/tree was counted. Tree yield $(\mathrm{kg})$ was estimated by fruits number/tree and fruit weight average.

3.5 . Fruit physical and chemical properties: At harvest time, three ripe fruits were taken from each tree to study the physical and chemical properties.

\section{A-Physical properties:}

1-Fruit weight: The average fruit weight $(\mathrm{g})$ was estimated by weighting samples from each replicate.

2-Pulp weight: pulp weight $(\mathrm{g})$ was estimated

3-Pulp weight $(\%)$ was counted as: (pulp weight/ fruit weight) $\times 100$

4-Fruit dimensions: Fruit length and width were measured by digital Caliper $(\mathrm{mm})$.

5- Fruit shape index: Fruit shape index =fruit length $(\mathrm{mm}) /$ fruit width $(\mathrm{mm})$ according to Sanaa (1996).

\section{B- Chemical properties:}

1- Total soluble solids percentage: was measured according to A.O.A.C.(2006) using a hand refractometer ATAGO, Japan (0-32).

2-Fruit acidity (\%) : Juice samples was filtered to estimate total acidity by the titration method against $\mathrm{NAOH}(0.1 \mathrm{~N})$ with phenol phethalein, as an indicator, according to (Chen and Mellenthin, 1981) .

3-TSS/ acid ratio: Calculated by divided the values of TSS/ acid ratio

4- Vitamin $\mathbf{C}$ content : This was defined in pure juice samples as $\mathrm{mg} / 100 \mathrm{ml}$ juice by (A.O.A.C, 2006) using $5 \mathrm{ml}$ juice sample and $5 \mathrm{ml}$ of oxalic acid solution (2\%), then titrated against 2,6-dichlorophenolendophenol dye to the end point to determine vitamin $\mathrm{C}$.

5- Fruit carotenoids: This was measured by A.O.A.C ( 2006) as (mg /100 ml filtered juice ).

\subsection{Statistical analysis:}

Data were subjected to analysis of variance according to Snedecor and Cochran (1982).General linear model procedure of the statistical analysis 
system SAS (2004) was used. Duncans New Multiple Range Test was used for multiple comparisons (Duncan,1955).

\section{RESULTS AND DISCUSSION}

\section{Effect of rootstocks on vegetative growth characteristics:}

Table1, showed that the thickness of scion and rootstock had significant differences in both seasons of study (2019 and 2020). The differences cleared that the average rootstock thickness gave more thickness than scion thickness in mango scion of Keitt in both seasons of study. In addition the rootstock of mango balady had more active than the second rootstock of succary ones of Keitt and Naomi variety, while the variety of Haydi gave the opposite data in the two seasons of study. The leaf area showed the significant of differences during the two seasons of study, which the leaf area of keitt and Naomi cultivars gave a high measurable than Haydi leaf area in both seasons of study. These results are agreement with Duran- zuazu (2006) which mentioned that rootstocks have a great significant effects on scion growth and gave the greatest number of the shoots and leaves with mango trees .Also Mng'omba, et al. (2010), Bhuiyan, et al. (2010) and Zayan, et al. (2011) added that the grafted mango varieties gave high girth (diameter) and the greatest number of leaves.

Table 2, cleared that the vegetative sprouts measuring showed the features of spring, summer and autumn which gave a significant differences in both seasons of study. These results showed spring growth number had significantly in both seasons of study. The results of spring characteristics in the rootstock of succary gave an increasing measurable than second rootstock of mango Balady as generally in both seasons of study. In this respect Keitt, Naomi and Haydi of these varieties showed that higher affecting by the previous rootstocks and can be desending order as generally Naomi than Haydi and later Keitt ones.

The summer sprouts cleared that in Table 2, a significant differences in both seasons of study. The rootstock of Balady gave more summer number than succary in the previous of mango Cultivars. Autumn growth number was affected by mango varieties which Naomi gave more number of autumn growth and Keitt variety came the second in this respect, while Haydi variety gave none autumn growth number in both study seasons. Rootstocks play role in this character, which Succary had highly number in both cultivars Keitt and Naomi than Balady one. 
Table 1. Effect of some mango rootstocks (scion thickness $(\mathrm{mm})$, rootstock thickness $(\mathrm{mm})$ and the average leaf area $\left(\mathrm{cm}^{2}\right)$ )of some mango varieties during 2019 and 2020 seasons

\begin{tabular}{|l|c|c|c|c|c|c|}
\hline \multicolumn{1}{|c|}{$\begin{array}{c}\text { Parameters } \\
\text { Treatments }\end{array}$} & $\begin{array}{c}\text { Scion thickness } \\
(\mathbf{m m})\end{array}$ & \multicolumn{2}{c|}{$\begin{array}{c}\text { Rootstock } \\
\text { thickness }(\mathbf{m m})\end{array}$} & \multicolumn{2}{c|}{$\begin{array}{c}\text { Average leaf } \\
\text { area/cm }\end{array}$} \\
\cline { 2 - 8 } & $\begin{array}{c}\text { Season } \\
\mathbf{2 0 1 9}\end{array}$ & $\begin{array}{c}\text { Season } \\
\mathbf{2 0 2 0}\end{array}$ & $\begin{array}{c}\text { Season } \\
\mathbf{2 0 1 9}\end{array}$ & $\begin{array}{c}\text { Season } \\
\mathbf{2 0 2 0}\end{array}$ & $\begin{array}{c}\text { Season } \\
\mathbf{2 0 1 9}\end{array}$ & $\begin{array}{c}\text { Season } \\
\mathbf{2 0 2 0}\end{array}$ \\
\hline Keitt/Balady & $66.36 \mathrm{~A}$ & $71.30 \mathrm{~A}$ & $82.86 \mathrm{AB}$ & $87.80 \mathrm{~A}$ & $71.60 \mathrm{~B}$ & $85.51 \mathrm{~A}$ \\
\hline Keitt/Succary & $56.80 \mathrm{~B}$ & $65.63 \mathrm{~B}$ & $71.56 \mathrm{C}$ & $72.43 \mathrm{~B}$ & $74.96 \mathrm{~B}$ & $85.58 \mathrm{~A}$ \\
\hline Naomi/Balady & $46.10 \mathrm{D}$ & $50.13 \mathrm{D}$ & $62.43 \mathrm{D}$ & $65.33 \mathrm{C}$ & $79.63 \mathrm{~B}$ & $94.22 \mathrm{~A}$ \\
\hline Naomi/Succary & $66.06 \mathrm{~A}$ & $69.53 \mathrm{AB}$ & $84.83 \mathrm{~A}$ & $86.86 \mathrm{~A}$ & $103.5 \mathrm{~A}$ & $93.57 \mathrm{~A}$ \\
\hline Haydi/Balady & $45.43 \mathrm{D}$ & $48.83 \mathrm{D}$ & $80.56 \mathrm{~B}$ & $85.23 \mathrm{~A}$ & $34.82 \mathrm{C}$ & $46.61 \mathrm{~B}$ \\
\hline Haydi/Succary & $51.53 \mathrm{C}$ & $59.10 \mathrm{C}$ & $74.33 \mathrm{C}$ & $77.56 \mathrm{~B}$ & $33.37 \mathrm{C}$ & $46.91 \mathrm{~B}$ \\
\hline LSD(0.05) & $\mathbf{2 . 8 8 4}$ & $\mathbf{5 . 1 3 6}$ & $\mathbf{3 . 9 9 0}$ & $\mathbf{5 . 9 9 7}$ & $\mathbf{9 . 1 3 4}$ & $\mathbf{1 0 . 6 0}$ \\
\hline
\end{tabular}

Table (2). Effect of some mango rootstocks on average number of spring, summer and autumn growth cycle shoots of some mango varieties during 2019 and 2020 seasons

\begin{tabular}{|c|c|c|c|c|c|c|}
\hline \multirow{2}{*}{ Treatments } & \multicolumn{2}{|c|}{$\begin{array}{l}\text { number of spring } \\
\text { growth cycle shoots }\end{array}$} & \multicolumn{2}{|c|}{$\begin{array}{c}\text { number of } \\
\text { summer growth } \\
\text { cycle shoots }\end{array}$} & \multicolumn{2}{|c|}{$\begin{array}{c}\text { number of } \\
\text { autumn growth } \\
\text { cycle shoots }\end{array}$} \\
\hline & $\begin{array}{c}\text { Season } \\
2019\end{array}$ & $\begin{array}{c}\text { Season } \\
2020\end{array}$ & $\begin{array}{c}\text { Season } \\
2019\end{array}$ & $\begin{array}{c}\text { Season } \\
2020\end{array}$ & $\begin{array}{c}\text { Season } \\
2019\end{array}$ & $\begin{array}{c}\text { Season } \\
2020\end{array}$ \\
\hline Keitt/Balady & $3.083 \mathrm{C}$ & $\begin{array}{c}3.500 \\
\mathrm{C}\end{array}$ & $\begin{array}{c}4.666 \\
\mathrm{C}\end{array}$ & $\begin{array}{l}4.500 \\
\text { DC }\end{array}$ & $\begin{array}{l}1.916 \\
\mathrm{D}\end{array}$ & $\begin{array}{c}2.166 \\
\mathrm{D}\end{array}$ \\
\hline Keitt/Succary & $\begin{array}{c}4.583 \\
\text { B }\end{array}$ & $\begin{array}{c}4.666 \\
\text { B }\end{array}$ & $\begin{array}{c}5.833 \\
\mathrm{~A}\end{array}$ & $\begin{array}{c}6.000 \\
\mathrm{~A}\end{array}$ & $\begin{array}{c}3.916 \\
\text { B }\end{array}$ & $\begin{array}{c}4.083 \\
\text { B }\end{array}$ \\
\hline Naomi/Balady & $\begin{array}{c}3.083 \\
\mathrm{C}\end{array}$ & $\begin{array}{c}3.333 \\
\mathrm{C}\end{array}$ & $\begin{array}{l}5.750 \\
\mathrm{AB}\end{array}$ & $\begin{array}{c}5.750 \\
\mathrm{~A}\end{array}$ & $\begin{array}{c}5.166 \\
\mathrm{~A}\end{array}$ & $\begin{array}{c}5.333 \\
\mathrm{~A}\end{array}$ \\
\hline Naomi/Succary & $\begin{array}{c}5.083 \\
\mathrm{AB}\end{array}$ & $\begin{array}{c}5.416 \\
\mathrm{AB}\end{array}$ & $\begin{array}{l}3.666 \\
D\end{array}$ & $\begin{array}{c}3.833 \\
\mathrm{D}\end{array}$ & $\begin{array}{c}3.416 \\
\mathrm{C}\end{array}$ & $\begin{array}{c}3.416 \\
\mathrm{C}\end{array}$ \\
\hline Haydi/Balady & $\begin{array}{c}3.166 \\
\mathrm{C}\end{array}$ & $\begin{array}{c}3.083 \\
\mathrm{C}\end{array}$ & $\begin{array}{c}5.416 \\
B\end{array}$ & $\begin{array}{l}5.666 \\
\mathrm{AB}\end{array}$ & $\begin{array}{c}0.000 \\
\mathrm{E}\end{array}$ & $\begin{array}{c}0.000 \\
\mathrm{E}\end{array}$ \\
\hline Haydi/Succary & $\begin{array}{c}5.666 \\
\mathrm{~A}\end{array}$ & $\begin{array}{c}5.833 \\
\mathrm{~A}\end{array}$ & $\begin{array}{l}4.750 \\
\mathrm{C}\end{array}$ & $\begin{array}{c}4.833 \\
\mathrm{BC}\end{array}$ & $\begin{array}{c}0.000 \\
\mathrm{E}\end{array}$ & $\begin{array}{c}0.000 \\
\mathrm{E}\end{array}$ \\
\hline LSD(0.05) & 0.630 & 0.877 & 0.386 & 0.869 & 0.229 & 0.342 \\
\hline
\end{tabular}


The opposite results of Haydi cleared that it did not give any autumn growth number in both Succary and Balady in both seasons. Patel, et al. (2016) recorded better with more number of graft and greater sprouting percentage maybe due to the vigorous growth nature in the rajapuri rootstock.

\section{2- Effect of rootstocks on floral characteristics:}

The data in Table 3, showed that the average panicle length had significant differences in the two season of the study. However the rootstocks affected markedly in the parameter (Panicle length). Balady mango rootstock gave more length of panicle than succary are with the variety of Keitt and Naomi while the succary rootstock with the variety of Haydi gave more length than Balady rootstock in both seasons of the study. In addition the parameter of branches per panicle showed a significantly differences in the first and second seasons respectively. However branches/panicle in Keitt variety on its Balady and Succary rootstocks had shown insignificantly differences. The other varieties of Naomi and Haydi appear the differences in large number in Succary rootstocks than balady one the previous results are harmony with Asif et al. (2002) on mango varieties of Anwar Rataul, Dasehari and langra.

Table 3. Effect of some mango rootstocks on Panicle length and number of branches /Panicle of some mango varieties during 2019 and 2020 seasons

\begin{tabular}{|l|c|c|c|c|}
\hline \multicolumn{2}{|c|}{ Parameters } & \multicolumn{2}{c|}{ Panicle length(cm) } & \multicolumn{2}{c|}{$\begin{array}{c}\text { number of branches } \\
\text { /Panicle }\end{array}$} \\
\cline { 2 - 5 } Treatments & $\begin{array}{c}\mathbf{2 0 1 9} \\
\text { Season }\end{array}$ & $\begin{array}{c}\mathbf{2 0 2 0} \\
\text { Season }\end{array}$ & $\begin{array}{c}\mathbf{2 0 1 9} \\
\text { Season }\end{array}$ & $\begin{array}{c}\mathbf{2 0 2 0} \\
\text { Season }\end{array}$ \\
\hline Keitt/ Balady & $45.50 \mathrm{~A}$ & $45.50 \mathrm{~A}$ & $38.16 \mathrm{AB}$ & $38.75 \mathrm{AB}$ \\
\hline Keitt/ Succary & $42.50 \mathrm{~B}$ & $42.83 \mathrm{~B}$ & $37.58 \mathrm{AB}$ & $38.16 \mathrm{AB}$ \\
\hline Naomi/ Balady & $30.58 \mathrm{D}$ & $31.75 \mathrm{D}$ & $35.91 \mathrm{~B}$ & $36.25 \mathrm{~B}$ \\
\hline Naomi/Succary & $30.33 \mathrm{D}$ & $30.50 \mathrm{D}$ & $39.16 \mathrm{~A}$ & $39.08 \mathrm{~A}$ \\
\hline Haydi/ Balady & $22.75 \mathrm{E}$ & $23.25 \mathrm{E}$ & $28.00 \mathrm{C}$ & $29.00 \mathrm{C}$ \\
\hline Haydi/Succary & $33.91 \mathrm{C}$ & $34.83 \mathrm{C}$ & $38.58 \mathrm{~A}$ & $38.58 \mathrm{AB}$ \\
\hline LSD(0.05) & $\mathbf{1 . 5 1 2}$ & $\mathbf{1 . 7 3 7}$ & $\mathbf{2 . 4 4 3}$ & $\mathbf{2 . 5 4}$ \\
\hline
\end{tabular}

\section{3- Effect of rootstocks on fruit physical properties:}

Physical characters of fruits in three varieties (Keitt, Naomi and Haydi) were shown as affected by rootstocks were significant differences in the two 
seasons of study, which including fruit length ,fruit width and fruit shape . The character of fruit length showed that Keitt and Naomi equal in this character as respectively in both seasons in Table 4, while the later variety of Haydi cleared that the low length in fruits of this variety. The rootstock of Succary gave more length than the other roorstock of Balady. The other kind of mangoes width $(\mathrm{mm})$ cleared significant differences in both seasons of study. However, the width of Keitt variety had more number of width as compared to Naomi and Haydi varieties .on the other hand the rootstocks also cleared number in fruit width ,however the Succary give an increasing number of width as compared with the second rootstock of Balady one .

The fruit shape also was changed as shown in mango variety and the used rootstocks in this respect .The shape of Naomi and Keitt showed increasing in shape as compared in Haydi one. The physical properties in mango fruit and the rootstocks are harmony with Avilan et al. (1997) on Edward and Springfels had increasing their fruit size and weight as well as Tomy Atkins and Haden on the Gomera 3 rootstock gave the highest height .Also, Zuazo et al. (2005) and Goncalves et al. (1998) on shape and weight mangoes

Table 5. Showed that the important character in fruits during the two seasons of study and cleared that the significantly differences in these characters of fruit (fruit weight (g), pulp weight (g) and pulp weight \%) .Fruit weight of Keitt variety came a large weight followed Naomi and Haydi fruit is less in weight . Then the rootstock under this study showed that Succary gave a large fruit of Keitt than Balady ones in both seasons of study also, the same trend occurred with Naomi variety while the third variety of Haydi gave vic versa in both seasons with rootstocks. The second character of pulp weight $(\mathrm{g})$ showed a significantly differences in the seasons of study, which the pulp of Keitt variety gave a more weight of pulp followed Naomi showed second degree of pulp weight and the less pulp weight occurred in Haydi variety. The Succary rootstock gave a more weight of pulp while Balady rootstock gave a less weight of pulp in three varieties as compared to Succary. The third character of net ratio percentage cleared markedly differences in the two seasons of study. However, Keitt net ratio percentage in Succary rootstock gave a higher percentage than Balady rootstock in both seasons of study .Also, with Naomi and Haydi varieties take the same trend in the two seasons of study with Succary rootstock than Balady one.The present study the fruits of mango in weight and pulp weight in mango of Keitt ,Naomi and Haydi and their rootstocks were agreement with Avilan et al. (1997) and Gawankar et al. (2010) studied rootstock effect on the fruit size and shape of grafted cultivars 
Table 4. Effect of some mango rootstocks on fruit length, fruit width and fruit shape index of some mango varieties during 2019 and 2020 seasons

\begin{tabular}{|l|l|c|l|c|c|c|}
\hline \multirow{2}{*}{ Parameters } & \multicolumn{2}{|c|}{$\begin{array}{c}\text { Fruit } \\
\text { Length(mm) }\end{array}$} & \multicolumn{2}{l|}{ Fruit Width (mm) } & \multicolumn{2}{l|}{ Fruit Shape index } \\
\cline { 2 - 7 } Treatments & $\begin{array}{l}\mathbf{2 0 1 9} \\
\text { Season }\end{array}$ & $\begin{array}{c}\mathbf{2 0 2 0} \\
\text { Season }\end{array}$ & $\begin{array}{l}\mathbf{2 0 1 9} \\
\text { Season }\end{array}$ & $\begin{array}{c}\mathbf{2 0 2 0} \\
\text { Season }\end{array}$ & $\begin{array}{l}\mathbf{2 0 1 9} \\
\text { Season }\end{array}$ & $\begin{array}{c}\mathbf{2 0 2 0} \\
\text { Season }\end{array}$ \\
\hline Keitt/Balady & $121.7 \mathrm{~A}$ & $125.5 \mathrm{~A}$ & $90.56 \mathrm{~A}$ & $91.20 \mathrm{~A}$ & $1.346 \mathrm{~B}$ & $1.376 \mathrm{~B}$ \\
\hline Keitt/Sukkary & $126.7 \mathrm{~A}$ & $128.3 \mathrm{~A}$ & $90.53 \mathrm{~A}$ & $89.96 \mathrm{~A}$ & $1.400 \mathrm{AB}$ & $1.426 \mathrm{~A}$ \\
\hline Naomi /Balady & $121.9 \mathrm{~A}$ & $119.1 \mathrm{~B}$ & $86.58 \mathrm{AB}$ & $83.03 \mathrm{C}$ & $1.413 \mathrm{AB}$ & $1.436 \mathrm{~A}$ \\
\hline Naomi/Sukkary & $126.6 \mathrm{~A}$ & $122.9 \mathrm{AB}$ & $86.65 \mathrm{AB}$ & $88.53 \mathrm{AB}$ & $1.460 \mathrm{~A}$ & $1.390 \mathrm{AB}$ \\
\hline Haydi/Balady & $100.8 \mathrm{~B}$ & $100.7 \mathrm{C}$ & $85.80 \mathrm{AB}$ & $84.60 \mathrm{BC}$ & $1.173 \mathrm{C}$ & $1.190 \mathrm{C}$ \\
\hline Haydi/Sukkary & $99.63 \mathrm{~B}$ & $94.41 \mathrm{D}$ & $82.41 \mathrm{~B}$ & $82.11 \mathrm{C}$ & $1.206 \mathrm{C}$ & $1.153 \mathrm{C}$ \\
\hline LSD(0.05) & $\mathbf{6 . 2 3 1}$ & $\mathbf{6 . 0 8 3}$ & $\mathbf{6 . 5 3 2}$ & $\mathbf{5 . 3 1 6}$ & $\mathbf{0 . 0 8 5}$ & $\mathbf{0 . 0 4 7}$ \\
\hline
\end{tabular}

Table 5. Effect of some mango rootstocks on fruit weight/g, pulp weight/g and pulp weight percentage of some mango varieties during 2019 and 2020 seasons

\begin{tabular}{|c|c|c|c|c|c|c|}
\hline \multirow{2}{*}{ Preatments } & \multicolumn{2}{|c|}{ Fruit weight(g) } & \multicolumn{2}{|c|}{ Pulp weight(g) } & \multicolumn{2}{|c|}{ Pulp weight $\%$} \\
\hline & $\begin{array}{c}\text { Season } \\
(2019)\end{array}$ & $\begin{array}{c}\text { Season } \\
(2020)\end{array}$ & $\begin{array}{c}\text { Season } \\
(2019)\end{array}$ & $\begin{array}{c}\text { Season } \\
(2020)\end{array}$ & & $\begin{array}{c}\text { Season } \\
(2020)\end{array}$ \\
\hline Keitt// & $\begin{array}{c}495.0 \\
\text { B }\end{array}$ & $\begin{array}{c}507.0 \\
\text { B }\end{array}$ & $384.8 \mathrm{~B}$ & $\begin{array}{c}397.6 \\
\text { B }\end{array}$ & $\begin{array}{c}77.74 \\
\mathrm{AB}\end{array}$ & $\begin{array}{c}78.43 \\
\text { B }\end{array}$ \\
\hline Keitt/s & $551.8 \mathrm{~A}$ & $562.5 \mathrm{~A}$ & $451.8 \mathrm{~A}$ & $\begin{array}{c}460.3 \\
\text { A }\end{array}$ & $81.87 \mathrm{~A}$ & $\begin{array}{c}81.84 \\
\text { A }\end{array}$ \\
\hline Naomi & $356.8 \mathrm{D}$ & $352.3 \mathrm{D}$ & $258.1 \mathrm{D}$ & $282.1 \mathrm{D}$ & $\begin{array}{c}72.34 \\
\text { CD }\end{array}$ & $\begin{array}{c}80.09 \\
\mathrm{AB}\end{array}$ \\
\hline Nao & $\begin{array}{c}372.5 \\
\mathrm{C}\end{array}$ & $\begin{array}{c}370.3 \\
\mathrm{C}\end{array}$ & $300.5 \mathrm{C}$ & $\begin{array}{c}293.1 \\
\mathrm{C}\end{array}$ & $80.68 \mathrm{~A}$ & $\begin{array}{c}79.17 \\
\text { B }\end{array}$ \\
\hline Haydi/Balady & $\begin{array}{c}273.6 \\
E\end{array}$ & $\begin{array}{c}308.5 \\
\mathrm{E}\end{array}$ & $189.8 \mathrm{E}$ & $\begin{array}{c}225.0 \\
\mathrm{E}\end{array}$ & $69.28 \mathrm{D}$ & $72.92 \mathrm{C}$ \\
\hline Haydi/Suc & $271.6 \mathrm{E}$ & $\begin{array}{c}262.3 \\
F\end{array}$ & $200.5 \mathrm{E}$ & $\begin{array}{c}177.8 \\
F\end{array}$ & $\begin{array}{c}73.83 \\
\text { BC }\end{array}$ & $\begin{array}{c}67.82 \\
\text { D }\end{array}$ \\
\hline LSD(0.05) & 10.48 & 9.082 & 16.48 & 7.053 & 4.531 & 2.571 \\
\hline
\end{tabular}


studying scion/rootstock relationship. Also, Tandon and Kalra (1983) estimated that fruit weight of Dashehari cv mangoes had increased until 91 days after fruit set .In addition Lakshminarayana et al. (1970) indicated fruit of mango reached maturity stage during 16 weeks after fruit setting and the weight had continued increasing till harvest in terms of mangoes length and weight.

\section{4- Effect of rootstocks on fruit chemical properties:}

The present study in Table ,6 showed a significantly differences in this character during the varieties in both seasons of study however, the variety Keitt came a highly numbers of TSS in the two seasons of the study as compared to these varieties (Haydi and Naomi) which cleared less contents in both seasons of TSS. Also, those rootstocks in this study were insignificant in each variety of the two seasons. Seasons of study. However, the succary rootstock gave a higher acidity in all varieties of study than the other rootstock of Balady mango in all varieties of study (Keitt, Naomi and Haydi) respectively. The character of TSS/Acid ratio showed significant differences, in both seasons of study. The highest content of TSS/Acid ratio appeared in variety of Keitt mangoes followed by Naomi and then Haydi is less content of TSS/Acid ratio respectively. The previous results of chemical properties of Keitt, Naomi and Haydi fruits are agreement with Mamiro et al. (2007) on TSS 18.9 in Dodo mango, also Andrew et al. (1985) on acidity lack and increasing in $\mathrm{pH}$ value .Malic acid and citric acid were reported to be greatest organic acids a large reduction in citric acid .Also, Othman and Mbogo (2009) studied on ascorbic acid in mangoes and high percentage of TSS.

Table 7, Showed that carotene content of mangos was a significant differences in both seasons of the study .However, mango variety of Haydi cleared high content of carotene followed by Naomi and Keitt had low content of carotene in both seasons. The rootstocks showed that there were effects on this character of mango varieties. Balady rootstock gave a higher content of carotene as compared with Succary rootstock in seasons of study. In addition, Vitamin C (ascorbic acid) was affected by the rootstocks, however the highest content of V.C cleared in Balady mango as rootstock with Naomi one while the other rootstock of Succary showed a high content of carotene with variety of Keitt than Balady one.Also, in the two rootstocks with Haydi variety appeared equal differences markedly in both seasons of study.Carotene and ascorbic acid were affected by different rootstocks and mango varieties .The previous results were agreement with Appiah et al. (2011) on reduction in 
Table 6. Effect of some mango rootstocks on TSS, total acidity percentage and TSS/ Acid ratio of some mango varieties, during 2019 and 2020 seasons

\begin{tabular}{|l|c|c|c|c|c|c|}
\hline \multirow{2}{*}{ Parameters } & \multicolumn{2}{|c|}{ TSS } & \multicolumn{2}{c|}{ Total acidity \% } & \multicolumn{2}{c|}{ TSS/Acid ratio } \\
\cline { 2 - 7 } Treatments & $\mathbf{( 2 0 1 9 )}$ & $\mathbf{( 2 0 2 0})$ & $\mathbf{( 2 0 1 9 )}$ & $\mathbf{( 2 0 2 0 )}$ & $\mathbf{( 2 0 1 9 )}$ & $\mathbf{( 2 0 2 0 )}$ \\
Season & Season & Season & Season & Season & Season \\
\hline Keitt/Balady & 18.33 & 18.66 & 0.136 & 0.156 & 134.5 & 120.03 \\
& $\mathrm{~A}$ & $\mathrm{~A}$ & $\mathrm{D}$ & $\mathrm{C}$ & $\mathrm{A}$ & $\mathrm{A}$ \\
\hline Keitt/Succary & 18.66 & 19.00 & 0.253 & 0.246 & 74.27 & 77.42 \\
& $\mathrm{~A}$ & $\mathrm{~A}$ & $\mathrm{~B}$ & $\mathrm{~B}$ & $\mathrm{C}$ & $\mathrm{BC}$ \\
\hline Naomi/Balady & 12.16 & 11.33 & 0.220 & 0.233 & 55.30 & 48.58 \\
& $\mathrm{D}$ & $\mathrm{C}$ & $\mathrm{C}$ & $\mathrm{B}$ & $\mathrm{D}$ & $\mathrm{D}$ \\
\hline Naomi/Succary & 12.16 & 12.00 & 0.130 & 0.150 & 93.88 & 80.41 \\
& $\mathrm{D}$ & $\mathrm{C}$ & $\mathrm{D}$ & $\mathrm{C}$ & $\mathrm{B}$ & $\mathrm{B}$ \\
\hline Haydi/Balady & 13.83 & 14.50 & 0.313 & 0.303 & 43.85 & 48.68 \\
& $\mathrm{C}$ & $\mathrm{B}$ & $\mathrm{A}$ & $\mathrm{A}$ & $\mathrm{E}$ & $\mathrm{D}$ \\
\hline Haydi/Succary & 15.50 & 15.66 & 0.203 & 0.220 & 77.03 & 70.28 \\
& $\mathrm{~B}$ & $\mathrm{~B}$ & $\mathrm{C}$ & $\mathrm{B}$ & $\mathrm{C}$ & $\mathrm{C}$ \\
\hline LSD(0.05) & $\mathbf{1 . 4 5 4}$ & $\mathbf{1 . 9 4 8}$ & $\mathbf{0 . 0 2 0}$ & $\mathbf{0 . 0 4 2}$ & $\mathbf{4 . 7 7 4}$ & $\mathbf{7 . 8 8 1}$ \\
\hline
\end{tabular}

Table 7. Effect of some mango rootstocks on carotene $\mathrm{mg} / 100 \mathrm{gm}$ and Vitamin $\mathrm{C} \mathrm{mg/100ml} \mathrm{of} \mathrm{some} \mathrm{mango} \mathrm{varieties} \mathrm{during} 2019$ and 2020 seasons

\begin{tabular}{|l|c|c|c|c|}
\hline \multirow{2}{*}{ Parameters } & \multicolumn{2}{|c|}{ Carotene mg/100gm } & \multicolumn{2}{c|}{ V.C mg/100ml } \\
\cline { 2 - 5 } Treatments & $\begin{array}{c}\text { Season } \\
\mathbf{( 2 0 1 9 )}\end{array}$ & $\begin{array}{c}\text { Season } \\
\mathbf{( 2 0 2 0})\end{array}$ & $\begin{array}{c}\text { Season } \\
(\mathbf{2 0 1 9})\end{array}$ & $\begin{array}{c}\text { Season } \\
(\mathbf{2 0 2 0})\end{array}$ \\
\hline Keitt/Balady & 3.540 & 2.883 & 8.60 & 9.320 \\
& $\mathrm{BC}$ & $\mathrm{C}$ & $\mathrm{C}$ & $\mathrm{D}$ \\
\hline Keitt/Succary & 2.793 & 2.943 & 12.54 & 12.90 \\
& $\mathrm{C}$ & $\mathrm{C}$ & $\mathrm{BC}$ & $\mathrm{C}$ \\
\hline Naomi/Balady & 3.490 & 3.216 & 31.53 & 36.55 \\
& $\mathrm{BC}$ & $\mathrm{C}$ & $\mathrm{A}$ & $\mathrm{A}$ \\
\hline Naomi/Succary & 3.423 & 4.036 & 32.96 & 33.68 \\
& $\mathrm{BC}$ & $\mathrm{BC}$ & $\mathrm{A}$ & $\mathrm{B}$ \\
\hline Haydi/Balady & 4.296 & 4.700 & 16.12 & 15.05 \\
& $\mathrm{~B}$ & $\mathrm{~B}$ & $\mathrm{~B}$ & $\mathrm{C}$ \\
\hline Haydi/Succary & 7.266 & 9.410 & 15.76 & 14.33 \\
& $\mathrm{~A}$ & $\mathrm{~A}$ & $\mathrm{~B}$ & $\mathrm{C}$ \\
\hline LSD(0.05) & $\mathbf{1 . 2 8 0}$ & $\mathbf{1 . 2 3 1}$ & $\mathbf{4 . 9 6 7}$ & $\mathbf{2 . 8 4 9}$ \\
\hline
\end{tabular}


vitamin c of mango and Xiao and Hongwu (2013) illustrated significantly greater contents of B-carotene.

\section{5- Effect of rootstocks on fruits number and yield /tree:}

Table 8, Showed that in yield of mango varieties in features of fruits number/tree and yield/tree $(\mathrm{kg})$ showed a significant differences in the two seasons of study. The first feature in fruit number/tree cleared that Naomi was higher number/tree followed Keitt and later Haydi in this character in both seasons. The rootstocks showed effect in this character of fruit number, which the Succary rootstock came more fruits than Balady one in all varieties (Keitt ,Naomi and Haydi) in both seasons. The second character of yield/tree( $\mathrm{kg}$ ) showed that Keitt gave a more yield followed Naomi and later in Haydi was the least yield per tree.As generally the rootstock of Succary gave more yield /tree than the other rootstock of Balady one in the two seasons of study. This was in agreement with Andrés, et.al. (2019) studied that rootstocks would modify fruit yield ,total soluble solids content and mango fruit quality all this to improve yield and mangoes quality grafted on various rootstocks to identify possibility using in high density planting (Chandan, et al. , 2006). Langra grown on Bappakai rootstock gave the highest fruit number per plant following by Vellaikulumban.

Table 8. Effect of some mango rootstocks on number of fruits /tree and yield /tree of some mango varieties during 2019 and 2020 seasons

\begin{tabular}{|l|c|c|c|c|}
\hline \multirow{2}{*}{ Parameters } & \multicolumn{2}{c|}{ Number of fruits /tree } & \multicolumn{2}{c|}{ Yield /tree( kg) } \\
\cline { 2 - 5 } Treatments & $\begin{array}{l}\mathbf{2 0 1 9} \\
\text { Season }\end{array}$ & $\begin{array}{c}\mathbf{2 0 2 0} \\
\text { Season }\end{array}$ & $\begin{array}{c}\mathbf{2 0 1 9} \\
\text { Season }\end{array}$ & $\begin{array}{c}\mathbf{2 0 2 0} \\
\text { Season }\end{array}$ \\
\hline Keitt / Balady & $58.66 \mathrm{~A}$ & $64.33 \mathrm{~A}$ & $29.03 \mathrm{~A}$ & $32.623 \mathrm{~A}$ \\
\hline Keitt / Succary & $56.00 \mathrm{~A}$ & $49.33 \mathrm{C}$ & $30.89 \mathrm{~A}$ & $27.757 \mathrm{~B}$ \\
\hline Naomi / Balady & $58.66 \mathrm{~B}$ & $57.00 \mathrm{~B}$ & $20.94 \mathrm{~B}$ & $20.073 \mathrm{C}$ \\
\hline Naomi / Succary & $60.33 \mathrm{~A}$ & $60.00 \mathrm{AB}$ & $22.48 \mathrm{~B}$ & $22.227 \mathrm{C}$ \\
\hline Haydi / Balady & $42.00 \mathrm{~B}$ & $32.33 \mathrm{D}$ & $11.477 \mathrm{C}$ & $9.980 \mathrm{D}$ \\
\hline Haydi / Succary & $30.00 \mathrm{C}$ & $30.66 \mathrm{D}$ & $8.153 \mathrm{C}$ & $8.040 \mathrm{D}$ \\
\hline LSD(0.05) & $\mathbf{9 . 5 4 4}$ & $\mathbf{4 . 7 1 6}$ & $\mathbf{4 . 1 9 9 1}$ & $\mathbf{2 . 2 7 1}$ \\
\hline
\end{tabular}

\section{CONCLUSION}

Under the conditions of this experiment, the important idea for trees in vegetative ,flower status, yield, physical and chemical characters of fruits came in studying and discussed what happened and also must be selected. The 
rootstocks and its scions to get the good total yield and the best character of fruit which agreement the consumption especially in this kind of mango fruit to realize in that name of queen fruit in the kingdom of horticulture plants in all world of fruits.

\section{REFERENCE}

A.O.A.C. (2006). Official Methods of Analysis . A.O.A.C. International ,W. Horwitz (Ed.).AOAC Int.

Ahmed, F.F. and Morsy, M.H. (1999). A new method for measuring leaf area in different fruit species. J. Agric. Rec.\& Dev.,19: 97-105.

Amin, R.S. (1978). In-situ soft wood grafting in mango. Indian Hort., (23):9-10.

Andrés R.M.; Antonio, N.; Martínez, L.R.; Rosa, E. A. B. and García, L.R. (2019). Effect of rootstock in tree growth, dry matter, flowering, yield and quality of Manila mango. Scientia Hort., (251): 155-161

Appiah, F., Kumah, P. and Idun, I. (2011). Effect of ripening stage on composition, sensory qualities and acceptability of keitt mango (Mangifera indica L.)African Journal Of Food, Agriculture ,Nutrition and Development , 11:.(5): 5096-5109.

Andrew P. Medlicott, A.P.,Anthony K. Thompson,A.K. (1985). Analysis of sugars and organic acids in ripening mango fruits (Mangifera indica $\mathrm{L}$. var Keitt) by high performance liquid chromatography. Journal of the Science Of Food And Agriculture, 36( 7 ):561-566.

Asif M., Usman, M., Jaskani, M. J. And Khan, M.M. (2002). Comparative study of flower sex ratio in different cultivars of mango (mangifera indica L). International J. Of Agriculture \& Biology, (4)2: 220-222.

Avilan, R.L., Leal F., Rodriguez, M., Ruiz, J. and Marin, C.R. (1997). Mango rootstocks and their influence on fruit shape and size. Acta Horti., (455): 479-488.

Bhuiyan, M.F.A., Rahim, M.A. and Alam, M.S. (2010). Study on the growth of plants produced by epicotyl (stone) grafting with different rootstockscion combinations in mango. J. Agrofor. Environ., 3 (2):163-166.

Chandan, P. M., Kadam, J. H. and Ambad, S. N. (2006). Effect of different polyembryonic and monoembryonic rootstocks on performance of Dashehari mango. Inter. J. Agri. Sci., 2 (2): 594-595. 
Chen, P.M. and Mellenthin, W.M. (1981). Effect of harvest date on ripening capacity and post -harvest life of Anjou Pears. J. Amer. Soc. Hort., Sci., 106:38.

Duncan,D.B.(1955).Multiple range and Multiple F test .Biometrics,11:1-42.

Duran-zuazu, V.H. (2006). Fruit yield, plant growth and nutrient statues in mango as effect of rootstocks. Inter. J. F. Sci., 5 (4): 3-21.

Gawankar, M.S., Salvi, B.R., Chavan, S.A. and Dalvi, N.V. (2010). Comparative performance of mango varieties grafted on Vellaikolamban and mixed rootstock. J. Hort. Sci., 5 (2): 114-116.

Goncalves, N.B., Carvalho, V.D., Goncalves, J.R., Coelho, S.R.M. and Silva, T.G. (1998). Physical and chemical characterization of fruits of mango (Mangifera indica L.) cultivars, Ciênc. Agro-tec., (22): 72-78.

Kaur, G. and Malhi, C.S. (2006). Effect of age of rootstock and growing medium on the success of epicotyl grafting in mango. Indian J. Hort., 63(3): 244-247.

Lakshminarayana S., Subhadra, N.V. and Subramanyam, H. (1970). Some aspects of developmental physiology of the mango fruit. Journal of Horticultural Science .,45 (2):133-142.

Mamiro, P., Fweja, L., Chove, B., Kinabo, J., George, V. and Mtebe K (2007). Physical and chemical characteristics of off-vine ripened mango (Mangifera indica L) fruit (Dodo). African J. of Biotech: 6 (21): 2477-2483.

Mng'omba, S.A., Akinnifesi, F.K., Gudeta, S. and Ajayi, O.C. (2010). Rootstock growth and development for increased graft success of mango (Mangifera indica) in the nursery. African Journal of Biotechnology, 9 (9): 1317-1324.

Omayma M. I. and Sanaa E. (2013). Evaluation of some Mango Inter stock on Kiett Scion Growth,. 3(1): ISSN 2347-6893.

Othman O.C. and GP Mbogo (2009). physico-chemical characteristics of storage-ripened mango (Mangifera indica $L$.) fruits varieties of eastern Tanzania. Journal of Sci., (35):58-65.

Patel B. B., Tank R. V. And Bhandari, A. J. (2016). response of rootstocks and varieties on growth and survival percentage in epicotyl grafting of mango (Mangifera indica L.). An International Quarterly Journal Of Life Sciences; 11(1): 479-483.

Reddy, Y. T. N., Reju, M., Kurian, P. R., Ramachander, Gorakh Singh and Kohli, R. R. (2003). Long term effects of rootstocks on growth, fruit yielding patterns of Alphonso mango (Mangifera indica L.) Scientia Hort., 97(2): 95-108 . 
Sanaa, S.Ebeed.(1996).Further studies on flowering and fruiting of mango trees .ph. D. Thesis ,Fac .of Agric. Ain Shams Univ. Egypt.

Smith, M.W., Hoult, M.D. and Bright, J.D. (2003). Rootstock affects yield, yield efficiency and harvest rate of Kensington pride Mango..Hort. Science, 38(2): 273-276.

Snedecor, G. W. and Cochran ,W.C (1982). Statistical Methods . $8^{\text {th }}$ Edition, lowa State University Press ,Ames ,Lowa, U.S.A.

Tandon, D. K. and Kalra, S.K. (1983) . Changes in sugars, starch and amylase activity during development of mango fruit cv. Dashehari. Journal Of Horticultural Science .,58(3)449-453.

Xiao X.-J. and Hongwu S. H. (2013) Physico-chemical and antioxidant properties of four mango (Mangifera indica L.) cultivars in China. Journal of Food Chemistry., 138 (1): 396-405.

Zayan, M., Elmorsy, A., Abou Elyazid, D.M. And Mazen, W.F.Y. (2020). Comparisons of Four Mango rootstocks and Their Effect on Naomi variety growth and Nutritional status. J. Plant Production Mansoura Univ.,11(10):1007-1011.

Zayan, M., Zeerban, S., EI Samak, A.and Ezzat, A.(2011). Evaluation study for the effect of four mango rootstocks on behaviour of Keit mango variety. International Journal of Horticultural Science, 17 (4-5): 4953.

Zuazo, V.H D., Pleguezueloa, C. R.R.and Tarifab, D. F. (2005). Fruit yield, growth and leaf-nutrient status of mango trees grafted on two rootstocks in a marginal growing area (South-East Spain). Fruits, 61(3):163-170.

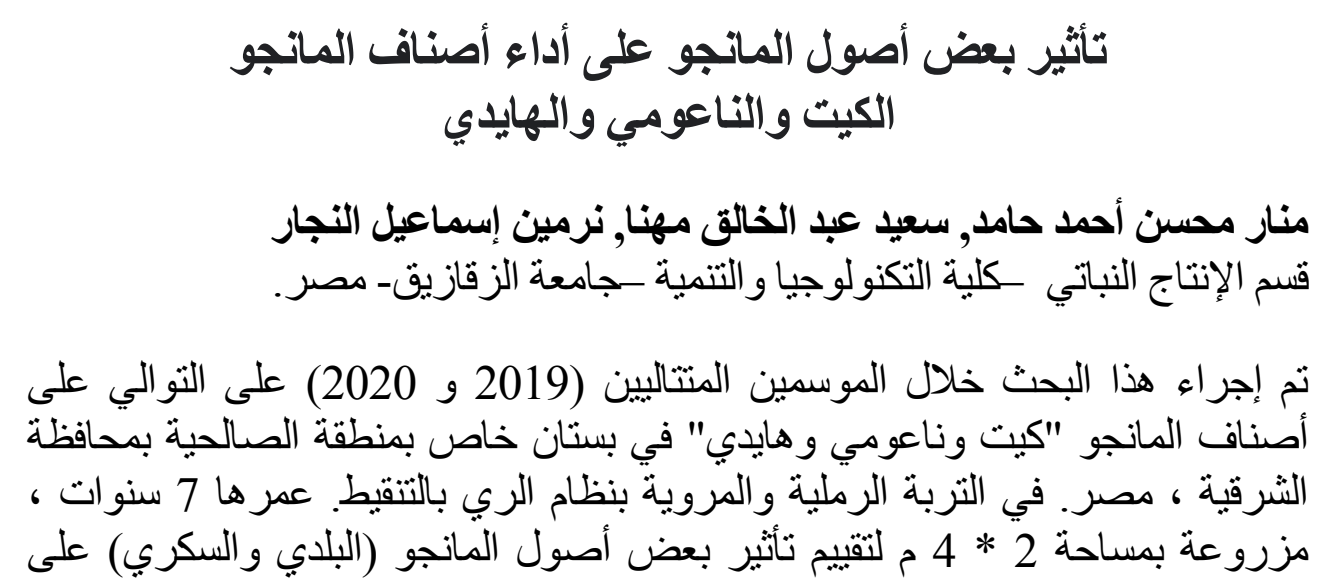


النمو الخضري ، الإزهار ، الإثمار ، المحصول والثماروجودة أصناف المانجو "كيت وناعومي و هايدي". وجد هناك علاقة بين أصول المانجو وتأثير ها علي الاصناف من حيث الصفات النباتية

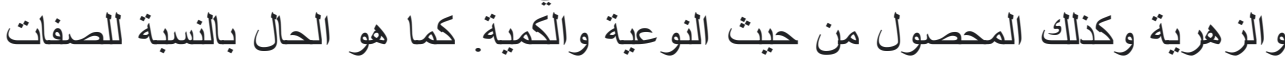
الخضرية ، سمك الأصل ، و التي أظهرت الفرون الفروق في أصناف كيت وناعومي وهايدي.

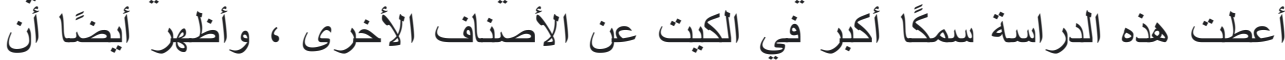

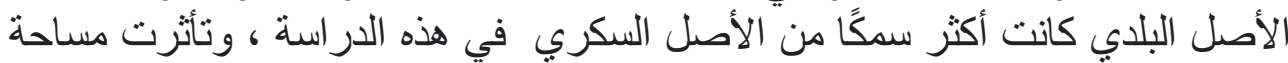

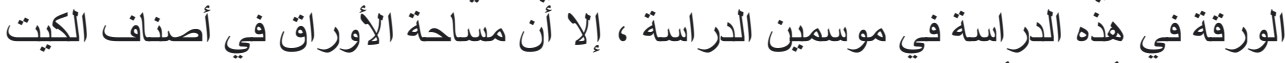

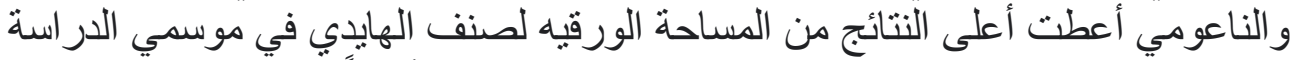

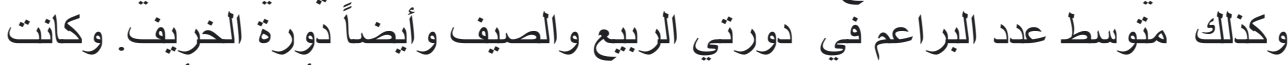

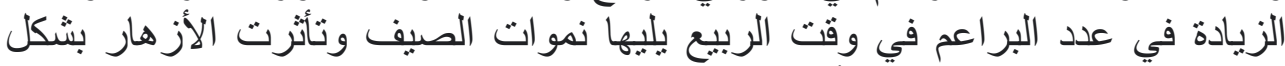

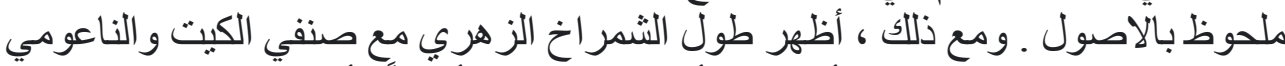

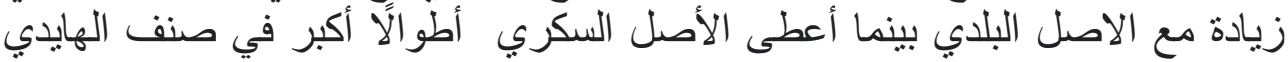

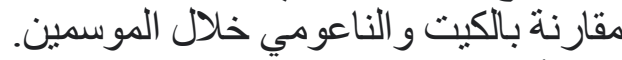

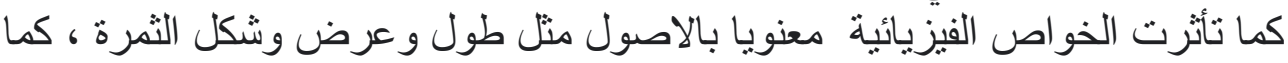

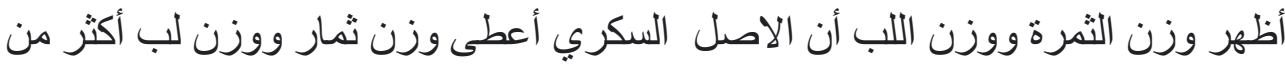

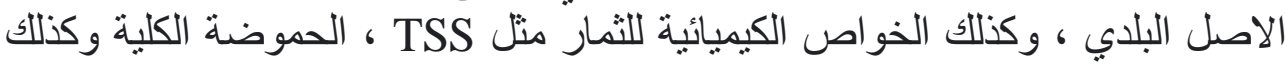

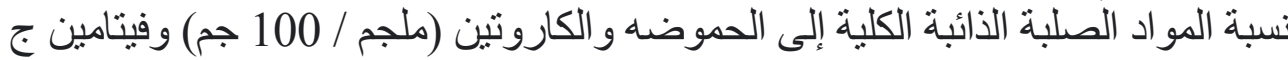

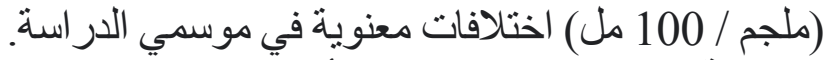

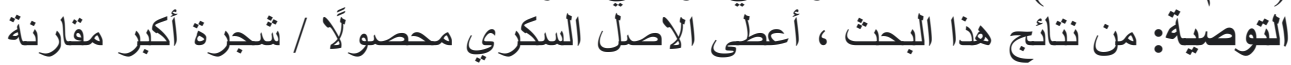
بالاصل البلدي في موسمي الدراسة حيث عمر الاشجار 7 سنو ات . 